ppi $201502 Z U 4645$

Esta publicación científica en formato digital es continuidad de la revista impresa ISSN-Versión Impresa 0798-1406 / ISSN-Versión on line 2542-3185Depósito legal pp $197402 Z$ U34
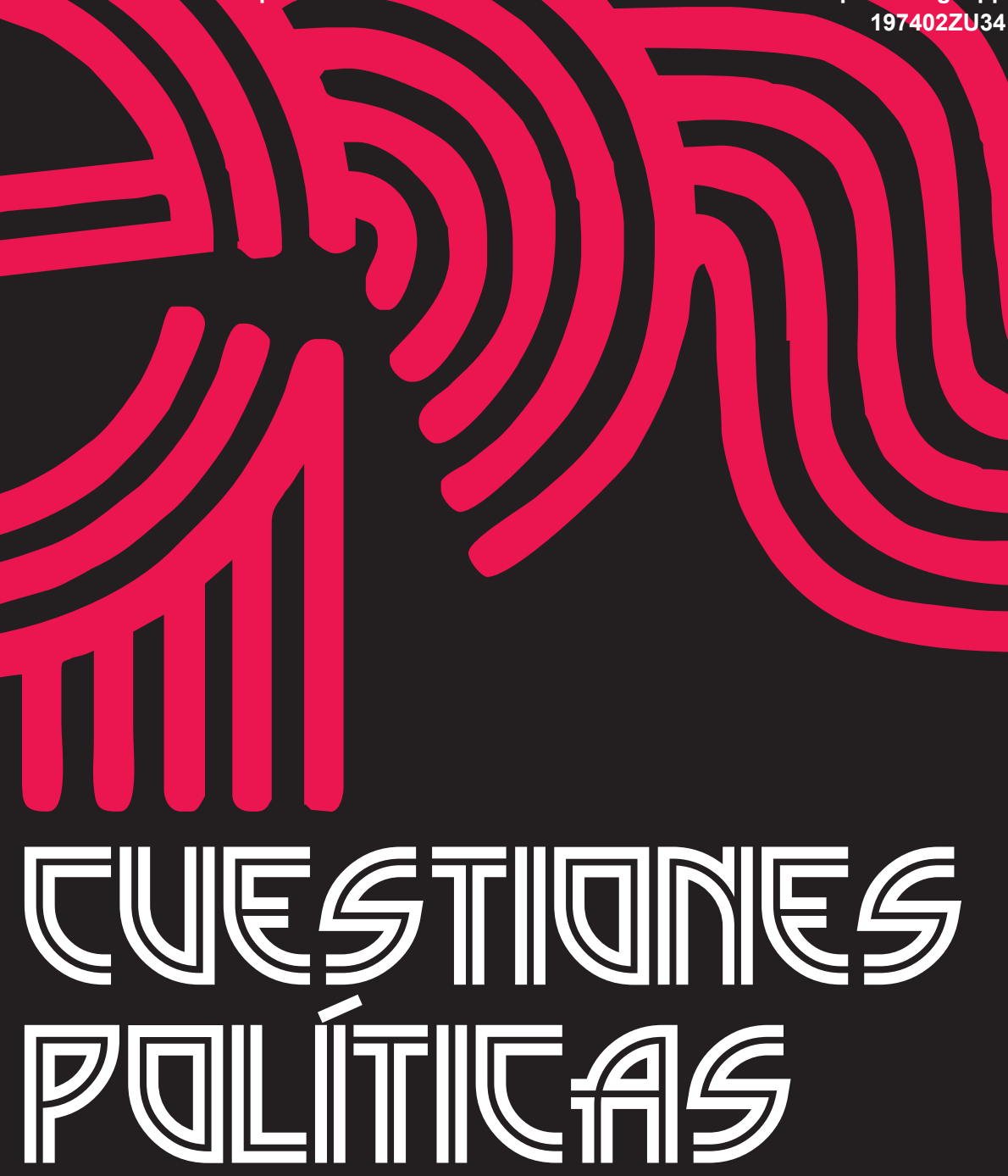

Instituto de Estudios Políticos y Derecho Público "Dr. Humberto J. La Roche" de la Facultad de Ciencias Jurídicas y Políticas de la Universidad del Zulia Maracaibo, Venezuela
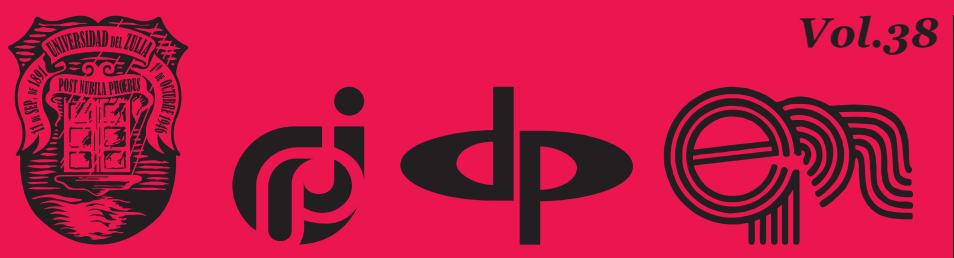

$N^{\circ}$ Especial 2da Parte 2020 


\title{
Civil Identity of Youth in the Conditions of Regional Social and Political Tension
}

\author{
DOI: https://doi.org/10.46398/cuestpol.382e.01
}

\section{Iana Alexeevna Siruikova * Evgeniya Valer'evna Khramova **}

\begin{abstract}
The article discusses the process of building the civil identity of young people in conditions of social and political tension, from a regional perspective. The formation of civic identity is a real problem of modern Russian society. The process is complicated by changes in the socio-political of the various regions. The media stimulates public discourse around the protest activity of young people. In the context of this scientific interest, the research presented in this article is carried out. Its empirical material is obtained during a grant study by the authors at the end of 2019. The research methodology is based on conflict resolution technology. As an empirical basis, materials from three focus group surveys, fifteen in-depth interviews and regional-minded internet resource content analysis on the topics of socio-political youth activity were interpreted. It is concluded that the republic of Tartaristan, as one of the regions of the Russian federation that has specifics in its economic, ethnic, and religious life, has become a platform for gathering empirical information.
\end{abstract}

Keywords: civil identity of youth; social identities; conditions of social tension; regional policy in Russia; collective imaginaries.

Senior lecturer of department of conflict resolution studies institute of social and philosophical sciences and mass communications, Kazan federal university. ORCID ID https://orcid.org/oooo-0oo1-60361383. Email: janellin@mail.ru

** Associate professor of department of conflict resolution studies institute of social and philosophical sciences and mass communications. Kazan federal university. ORCID ID: https://orcid.org/ooooooo1-7281-8731. Email: eugenlic@mail.ru 


\section{Civil Identity of Youth in the Conditions of Regional Social and Political Tensión \\ Identidad civil de la juventud en condiciones de tensión social y política regional}

\section{Resumen}

El artículo analiza el proceso de construcción de la identidad civil de la juventud en condiciones de tensión social y política, desde la perspectiva regional. La formación de la identidad cívica es un problema real de la sociedad rusa moderna. El proceso se complica por los cambios en el entorno sociopolítico de las diversas regiones. Los medios estimulan el discurso público en torno a la actividad de protesta de los jóvenes. En el contexto de este interés científico se llevó a cabo la investigación presentada en este artículo. Su material empírico se obtuvo en el transcurso de un estudio de subvención realizado por los autores a finales de 2019. La metodología de la investigación se basa en la tecnología de resolución de conflictos. Como base empírica se interpretaron además los materiales de tres encuestas de grupos focales, quince entrevistas en profundidad y análisis de contenido de recursos de internet de relevancia regional sobre los temas de la actividad sociopolítica de la juventud. Se concluye que, la república de Tartaristán, como una de las regiones de la federación rusa que posee características específicas en su vida económica, étnica y religiosa, se ha convertido en una plataforma para recopilar información empírica.

Palabras clave: identidad civil de la juventud; identidades sociales; condiciones de tensión social; política regional en Rusia; imaginarios colectivos.

\section{Introduction}

The study of state identity in the conditions of instability in the formation of the modern russian youth form is relevant and timely. The article summarizes the research experience of young conflict scientists at kazan federal university. A survey of modern russian youth was carried out in the framework of actual methodology. The authors have chosen as an object of study - a highly interesting concept of civic identity, conducted an applied study to identify the specifics of its formation in the conditions of the republic of tatarstan.

The research is based on the methodology of conflict audit and a set of socio-political theories on the explanation of social identities. The marketing component offers a methodology to explain some aspects of youth protest

activity in the region. 


\section{Methods}

The theoretical discussion around the concept of "civic identity" today is very extensive, international, and interdisciplinary. Its basis is social and political sciences. Some authors acknowledge that at the present, the formation of identity is perceived as a continuous process, which includes the interpretation and reinterpretation of experiences experienced by subjects (Nikraftar, 2017). Sociological studies of identity show that a significant part of the formation of collective identity lies in the framework of establishing social boundaries between one's own and other social groups through social comparison processes. For this purpose, assessments within and outside groups are often biased and interpreted in favor of (Müller, 2013).

A fairly large number of applied researches is conducted in the direction of analysis of teenage and youth identity. They imply that teens must understand their relationships with groups with different identities. They recognize the importance of the internet environment in shaping identity. It is believed that this social environment is characterized by limited parental intervention and a strong presence of teenage peers. This environment makes it possible to socialize, as well as design and discuss the teenager his personality (Van Eldik et al., 2019).

The authors pay special attention to the distinction between the concepts of "identity" and "belonging". When breeding these concepts, they usually mean that "identity" emphasizes the uniformity of any collective unit, and "belonging" emphasizes commonality, but not necessarily the same (PfaffCzarnecka, 2011).

In the scientific literature, the significance of each paradigm is noted. Each is recognized as useful for understanding phenomena in their respective fields of research. But it is noted that in the literature on identity, more attention is required to understanding the relationship of personal identity problems with socially constructed identity problems and their meanings for behavior, values, and well-being (Levitan et al., 2018). A common feature of the theoretical research presented in the literature, as a rule, is relying not on a quantitative, but on a qualitative research methodology.

The basis of the methodology of the study is a conflict resolution audit. This is a methodology for analyzing the socio-political tension of an object (a social group, community, location, or society as a whole), using marker and criterion technologies for analyzing discourse within the object of study as the main toolkit. The object is segmented by discourse (social, political, religious, ethnic, radical, gender, etc.) (Khramova et al., 2019). Markers of tension are identified in each segment. The degree of influence of marker 
semantics on the growth or decrease in tension is determined using the criteria component. In our case, the method of semantic differential is used when conducting focus group polls. When answering certain questions of the interview guide, respondents were asked to determine the level of significance of the indicator on a one-dimensional scale (from o to +10 units) (Hramova, 2020).

The empirical base of the research is the materials of three focus-group surveys of youth and youth experts in tatarstan, fifteen in-depth interviews and content analysis of internet resources of youth identity discourse. Focus groups have a specific characteristic. The first focus group was held among representatives of the young generation in the historical center of tatarstan, the museum-reserve - the city of bolgar.

The sample consisted of seven people, adolescents aged 14-17, with different socio-economic characteristics according to family affiliation. The group included both conformal and non-conformal and indifferent adolescents. The focus group can be described as provincial in terms of assessing the views of its participants. The second focus group included young residents of the capital of tatarstan - the city of kazan, both the indigenous population and visitors from other regions of russia. The group brought together young people with different, often polar, socio-political views. This group included both conformal representatives of the student activism of a classical university and non-conformal, often radical, representatives of the political underground, the opposition, ethnic and religious communities. The age was 19-25 years. The third focus group included representatives of the expert community of the republic of tatarstan dealing with issues of education, upbringing, and political socialization of youth. The average age of the participants was 45 years. The main task of the focus group survey was to compare the views of the expert community on youth identity with the real situation on civic identity formed by the participants of the youth community itself.

Representatives of various youth communities operating both online and offline were selected as respondents to in-depth interviews on the issue of youth civic identity formation. These are both formal and informal communities. Their activities are of the most diverse nature: political activism, social activism, ethnic and religious organizations. Some communities to which respondents belong can be classified as radicalized groups. Among the respondents, for example, are representatives of the headquarters of alexei navalny, one of the most famous russian opposition leaders; and representatives of radical sexist communities on social networks; and representatives of the youth islamic movement.

The main markers for identifying civic identity were such linguistic constructs that reveal the presence of: aggressive rhetoric against representatives of another identification group; rhetoric of classifying a 
subject as a member of a particular youth group (online or offline); the rhetoric of describing their objective socio-political reality; rhetoric of assessing the negativism and hopelessness of the future of modern youth; political protest rhetoric; rhetoric of social and political activism.

\section{Results and discussion}

The purpose of focus-group and in-depth interviews was to identify systemic manifestations (markers) of civic identity of youth in four groups: gender, confessional, opposition, subcultural. The reactions of society and the state to the manifestations of the civic identity of youth were analyzed. Civic identity is here the product of social differentiation and contradiction. Civic identity doesn't resolve them, but pushes the state and society to prohibitions and restrictions on youth, thereby provoking a civil youth protest.

The main objectives of the survey complex were:

- analysis of the rhetoric of youth on the problems of communication in online and offline communities, belonging to them, the use of the "language of aggression" and attitude to the state and society.

- identification of markers of ideological extremism in the expert discourse around the problem of civic identity.

- determination of the positions of young people in interaction with society and the state and their mutual obligations.

- study of the vision of modern youth by representatives of the expert community, its ideas about civic identity and the role of agents of political socialization and education of modern Russia in its formation.

- the search for a possible explanation for youth protest as an alternative to the current dominant "symbolic code" of elite groups.

- According to the results of an empirical study, in the communities of all examined segments, universal structural signs are found, such as:

- the dichotomy of "one's alien (enemy)".

- the presence of an ideological leader (only around which the community is viable).

- a certain set of supporters (according to experts, today it is 20-30 active people in the community). 
Iana Alexeevna Siruikova y Evgeniya Valer'evna Khramova
Civil Identity of Youth in the Conditions of Regional Social and Political Tensión

- prescribed forms of behavior for all actors (intolerant of specific enemies).

- a non-alternative system of views on reality and a pessimistic vision of the future of russian society.

Based on the findings of focus-group surveys and in-depth interviews testifying to the case-based and casual nature of interactions among youth communities, it can be determined that the absence of one or two structural features does not affect the development of others. So, in the group of anarchists the ideological leader may not be observed, but in the opposition politicized community - ideological prerequisites, except for slogans. But both the first and the second function, reproducing rhetoric, mechanics of action and strict adherence to technology influence on all members of the community, forming a collective civic identity.

The crisis of identity of modern youth is manifested in its negative orientation - the denial of similarity with any other age, social, gender, political groups, as well as fragmentation. Thus, the "fan of identities" is often in a state of existential conflict since no basic identity has been identified. In this role may be a civic identity. This feature of youth identity is actively used by ideologists of extremist movements in their interests. This is usually done through manipulative practices.

The manipulative technologies used by the ideologists of the communities are unrivaled in relation to the practices of political actors, who, due to their functional responsibilities, are entrusted with the struggle for the ideologization and political socialization of modern youth. The ideologists of extremist movements build community activities from practice to theory, and then to specific technology. Testing one technology, they, according to all scientific foundations, elevate it to the regime of established practice or eliminate it. A good example is the network structure of the "headquarters of a. Navalny" or npos created by "victims of the hands of the political regime".

This was the case with the transfer of technology of open protests and resistance to the technology of ordered preventive legal protection. Unlike the first protests (bolotnaya square in moscow, etc.), when various lawyers worked randomly with the detained protestants, at the moment there is an institute of professional lawyers specializing in working with "bulk" and other "protestors", and the "headquarters of navalny" and other "protest" ngos are staffed by lawyers.

There were no particular differences among representatives of urban and rural youth communities. This is not to say that rural youth have fewer or more markers of protest rhetoric of civic identity than urban youth. The differences are related to location, but not to identity. The basis of the difference is the sedentary vision of the future urban youth of tatarstan and 
mobile in rural areas. The lack of desire to change anything at the place of their rural residence does not encourage the youth of small towns and settlements to protest activity.

\section{Conclusion}

The study identified the following characteristics of the civic identity of modern youth:

- The lack of a clear formulation of political and social requirements both among young people in general and among representatives of youth communities of the most diverse kinds, in particular. The request for social justice, which is characteristic of all representatives of the youth socio-demographic group, does not structure at this stage clear requirements, except for a change of government.

- Substitution of requirements for the authorities and society with slogans of an extremist and radicalized nature, without a clear definition of strategies and tactics for their practical implementation.

- Lack of understanding among young people of the importance of isolating the interests of the opposite side of the conflict, that is, avoiding a rational awareness of the conflict, shifting unrealistic elements in the field with dominance (withdrawing the current government, social justice, fighting corruption);

- The transformation of protest from a form of political participation into a strategy to remove or increase social tension without looking for models of compromise or effective cooperation not only with the state, but also with society.

- The lack of a youth request for common ideological positions even within radicalized and purely political communities. The presence of stable ideological positions would facilitate the launch of internal integrative processes for these communities and stable recruiting. Here we can talk about the signs of the formation in russia of a kind of "generation of the thirteenth article" (article 13 of the constitution of the russian federation), which in its rejection of a unified ideology does not recognize constructive, system-forming, integrating principles of the significance of ideology.

An analysis of the rhetoric of a youth group around its civic identity when included in online and offline communities showed the presence of informal slang flowing from the internet environment into the real one. In verbal communication between communities, no differentiation 
of rhetorical devices was revealed. Aggressive rhetoric appears only in response to triggers artificially created during the conversation. Ideal fixations in the consciousness of these triggers were not found. Markers of aggressive attitude towards society in youth rhetoric are not observed. The persistent rejection of some elements of government is recorded in the majority of young people surveyed.

Among the markers of aggressive rhetoric in expert discourse, we-they dichotomy can be distinguished with respect to government representatives / elites. Linguistic units are distinguished: elite, power, system.

In contrast to the opinion of the expert community, youth representatives feel and express their obligations to society, not displaying extreme negativity in relation to the state. This is more like a situation of confusion, misunderstanding. In our opinion, young people are forced to engage in a narrow circle of their problems using the situation of ideological chaos in society. In the event of a critical violation of their rights and freedoms, representatives of the youth group themselves are ready to defend not only personal interests, but the whole society on the idea of social justice.

Representatives of the expert community highlight the totality of dysfunctions of state and public mechanisms in relation to youth. Attitude to this socio-demographic group varies from sympathetic to paternalistic. A low level of self-criticism and opportunities for influence and interaction with young people in solving their problems is noted. The problem of education is acute. The problem of education is not declared on the agenda of the expert community.

The youth protest is explained by experts as an alternative to the existing dominant "symbolic code" of elite groups. Young people themselves do not think in terms of elitization and symbolization of protest. The ideological basis of the protest for the youth itself is social justice.

\section{Acknowledgements}

The work is performed according to the russian government program of competitive growth of kazan federal university.

\section{Bibliographic References}

HRAMOVA, Elina. 2020. Markers of political identity in the study of ideological youth extremism. Relation of confessional, ethnic, regional and civil all- 
russian identity in the public and political environment of the republic of bashkortostan: collection of articles based on all-russian materials. Youth scientific school-conf., held march 26-28, 2020 - ufa: world of the press, $-256 \mathrm{p}$.

KHRAMOVA, Elizaveta; BOLSHAKOV, Andrey; IVANOV, Alexey; SHIBANOVA, Natalia. 2019. "Conflictology audit methodology: application practices in the study of aggression in the educational environment and youth ideological extremism” In: Kazan Pedagogical Journal. Vol. 6, pp. 205-210.

LEVITAN, Joseph; MAHFOUZ, Joseph; SCHUSSLER, Deborah. 2018. "Pragmatic identity analysis as a qualitative interview technique" In: Forum Qualitative Sozialforschung/Forum: Qualitative Social Research. Vol. 19, No. 3.

MÜLLER, Philipp. 2013. "National identity building through patterns of an international third-person perception in news coverage» In: International Communication Gazette. Vol. 8 No. 75, pp. 732-749.

NIKRAFTAR, Tayebeh. 2017. "Identity formation among teenagers: the role of training camp" In: International letters of social and humanistic sciences. Vol. 76, pp. 30-35.

PFAFF-CZARNECKA, Joanna. 2011. "From "identity" to "belonging" in social research: plurality, social boundaries, and the politics of the self" In: Working papers in development sociology and social anthropology. Vol. 18, p. 368.

VAN ELDIK, Anne; KNEER, Julia; JANSZ, Jeroen. 2019. "Urban \& online: social media use among adolescents and sense of belonging to a superdiverse city» In: Media and Communication. Vol. 2. No. 7, pp. 242-253. 
Vol.38 NEspecial

Esta revista fue editada en formato digital y publicada en diciembre de 2020, por el Fondo Editorial Serbiluz, Universidad del Zulia. Maracaibo-Venezuela 